\title{
Radiocarbon Dating of Anthropogenic Carbonates: What Is the Benchmark for Sample Selection?
}

\author{
Michael B. Toffolo \\ Institut de Recherche sur les Archéomatériaux-Centre de Recherche en Physique Appliquée à \\ l'Archéologie (IRAMAT-CRP2A), UMR 5060 CNRS, Université Bordeaux Montaigne, 8 Esplanade des Antilles, \\ 33607 Pessac, France; michael.toffolo@u-bordeaux-montaigne.fr
}

Received: 6 November 2020; Accepted: 21 November 2020; Published: 24 November 2020

\begin{abstract}
Anthropogenic carbonates are pyrotechnological products composed of calcium carbonate, and include wood ash, lime plaster/mortar, and hydraulic mortar. These synthetic materials are among the first produced by humans, and greatly influenced their biological and cultural evolution. Therefore, they are an important component of the archeological record that can provide invaluable information about past lifeways. One major aspect that has been long investigated is the possibility of obtaining accurate radiocarbon dates from the pyrogenic calcium carbonate that makes up most of these materials. This is based on the fact that anthropogenic carbonates incorporate atmospheric carbon dioxide upon the carbonation of hydrated lime, and thus bear the radiocarbon signature of the atmosphere at a given point in time. Since plaster, mortar, and ash are highly heterogeneous materials comprising several carbon contaminants, and considering that calcium carbonate is prone to dissolution and recrystallization, accurate dating depends on the effectiveness of protocols aimed at removing contaminants and on the ability to correctly identify a mineral fraction that survived unaltered through time. This article reviews the formation and dissolution processes of pyrogenic calcium carbonate, and mineralogical approaches to the definition of a 'dateable fraction' based on its structural properties.
\end{abstract}

Keywords: calcium carbonate; calcite; aragonite; plaster; mortar; hydraulic; ash; FTIR; cathodoluminescence; radiocarbon

\section{Introduction}

The ability to harness fire, called pyrotechnology, had a major impact on the cultural trajectory of modern humans, not only in terms of food production, warmth, and protection, but also in the development of new synthetic materials, such as lime plaster, ceramics, metals, and glass [1]. Two pyrotechnology products, lime plaster and wood ash, are composed of calcium carbonate $\left(\mathrm{CaCO}_{3}\right)$ [2]. Here, they are referred to as 'anthropogenic carbonates'. Lime plaster is produced by burning limestone to obtain quicklime, which is then slaked with water to form hydrated lime and allowed to react with atmospheric $\mathrm{CO}_{2}$ to form again $\mathrm{CaCO}_{3}$ [3]. Wood ash is the byproduct of the combustion of organics, and is mainly comprised of $\mathrm{CaCO}_{3}$ derived from the thermal decomposition of calcium oxalate crystals mineralized by plants [4]. Besides the wealth of information that these materials provide about human evolution, subsistence and adaptation strategies, ancient technology, and historic architecture [2,3,5], lime plaster and wood ash may contribute to the establishment of absolute chronologies. Both materials contain carbon of atmospheric origin, including the radiocarbon $\left({ }^{14} \mathrm{C}\right)$ isotope, and thus offer the possibility to obtain accurate age determinations when organic materials are not available [6].

The potential of anthropogenic carbonates for ${ }^{14} \mathrm{C}$ dating was first revealed in the 1960 s by Labeyrie and Delibrias [7,8], who measured the ${ }^{14} \mathrm{C}$ content of Roman and medieval lime mortars 
(i.e., lime plaster mixed with an aggregate) and calculated their ages with a fair degree of accuracy, considering that the study was performed before the development of the international calibration curve. Following attempts proved overall unsuccessful due to the occurrence of geologic and/or secondary carbonate components in lime mortars, which produced older apparent ages caused by 'dead' carbon or younger ages caused by environmental carbon [9-11]. In the 1990s and 2000s, the development of a refined carbon recovery method based on sequential acid hydrolysis of sieved fractions and the introduction of accelerator mass spectrometry (AMS) increased the accuracy of ${ }^{14} \mathrm{C}$ dates [12-18]. In the last 10 years, new purification and carbon recovery methods have been implemented, and the range extended to more challenging types of anthropogenic carbonate, such as wood ash and hydraulic mortars, with variable results [19-28]. A recent round-robin exercise among several ${ }^{14} \mathrm{C}$ laboratories confirmed that well-preserved aerial lime plasters may be accurately dated, whereas complex materials affected by hydraulic or secondary phases are still out of reach [29,30], although recent developments in thermal decomposition of contaminant phases appear promising [19]. Urbanová et al. [31] compiled a foresighted and up-to-date review of the history of the method and current challenges in ${ }^{14} \mathrm{C}$ dating of lime mortars.

All of the abovementioned studies are characterized by one common denominator: accurate ${ }^{14} \mathrm{C}$ dates may be obtained only if a pristine pyrogenic $\mathrm{CaCO}_{3}$ fraction is isolated and targeted for dating. A pristine fraction is defined here as an assemblage of crystals that did not undergo isotopic alteration after nucleation, and thus can be regarded as a closed carbon system that represents the time of formation of the artifact. In plaster/mortar, this is the pyrogenic $\mathrm{CaCO}_{3}$ produced upon carbonation of hydrated lime. In ash, it is the $\mathrm{CaCO}_{3}$ derived from the decomposition of calcium oxalates.

Pristine pyrogenic carbonate is a fundamental requirement for two reasons: (i) geogenic and diagenetic (secondary) phases are characterized by different formation paths compared to pyrogenic ones and therefore their carbon isotopic signatures introduce contamination, which ultimately results in inaccurate ages; (ii) knowing with certainty what phase is selected for AMS excludes potential bias or educated guesswork in the interpretation of ${ }^{14} \mathrm{C}$ measurements. Given the inherent heterogeneity of anthropogenic carbonates, it follows that a tailored characterization approach should be deployed in order to identify the desired target phases and avoid contaminants. However, this important aspect has been long understudied and limited to assumptions; only in the last decade have major efforts been put forward to assess the state of preservation of anthropogenic carbonates and understand how this information can be used to achieve accurate dates [19,32-42]. Of these, only a few tackled the crucial problem of defining a reference benchmark that can guide the selection of suitable archeological materials $[20-23,31,43,44]$. The main challenge is to find one or more proxies for the occurrence and preservation of pyrogenic phases that are widely applicable to anthropogenic carbonates, in a manner similar to the conventional quality controls for charcoal and collagen, which are based on vibrational spectroscopy and the fractionation of carbon and nitrogen isotopes [45-47].

This article reviews the formation and dissolution processes of anthropogenic carbonates found at archeological sites, the methods used for their characterization, and mineralogical approaches to the selection of pyrogenic $\mathrm{CaCO}_{3}$ phases, with the aim of providing context to the issue of setting the benchmark. In particular, this review will focus on establishing criteria for sample selection based on the basic structural properties of pyrogenic $\mathrm{CaCO}_{3}$ crystals.

\section{Formation and Dissolution Processes of Anthropogenic Carbonates}

\subsection{Lime Plaster and Lime Mortar}

Lime plaster is a binder that has been used as coating and decoration in constructions and ritual practices (e.g., plastered floors and walls, plastered human skulls, shrines, graves) or as support for visual art (e.g., frescoes) [1,3]. It derives from the thermal decomposition of a $\mathrm{CaCO}_{3}$ substrate, such as limestone, travertine, and marble, to $\mathrm{CaO}$ (quicklime) at temperatures above $800^{\circ} \mathrm{C}$. CaO reacts with liquid water to form $\mathrm{Ca}(\mathrm{OH})_{2}$ (hydrated lime; mineral name: portlandite), which subsequently 
incorporates atmospheric $\mathrm{CO}_{2}$ and turns back to $\mathrm{CaCO}_{3}$ upon setting $[3,48]$. The latter usually nucleates as micritic calcite but in some instances, aragonite may occur as well [49-51] (Figure 1a,b). The reaction can be summarized in three steps as follows:

$$
\begin{gathered}
\mathrm{CaCO}_{3} \stackrel{800{ }^{\circ} \mathrm{C}}{\longrightarrow} \mathrm{CaO}+\mathrm{CO}_{2} \\
\mathrm{CaO}+\mathrm{H}_{2} \mathrm{O}=\mathrm{Ca}(\mathrm{OH})_{2} \\
\mathrm{Ca}(\mathrm{OH})_{2}+\mathrm{CO}_{2}=\mathrm{CaCO}_{3}+\mathrm{H}_{2} \mathrm{O} .
\end{gathered}
$$
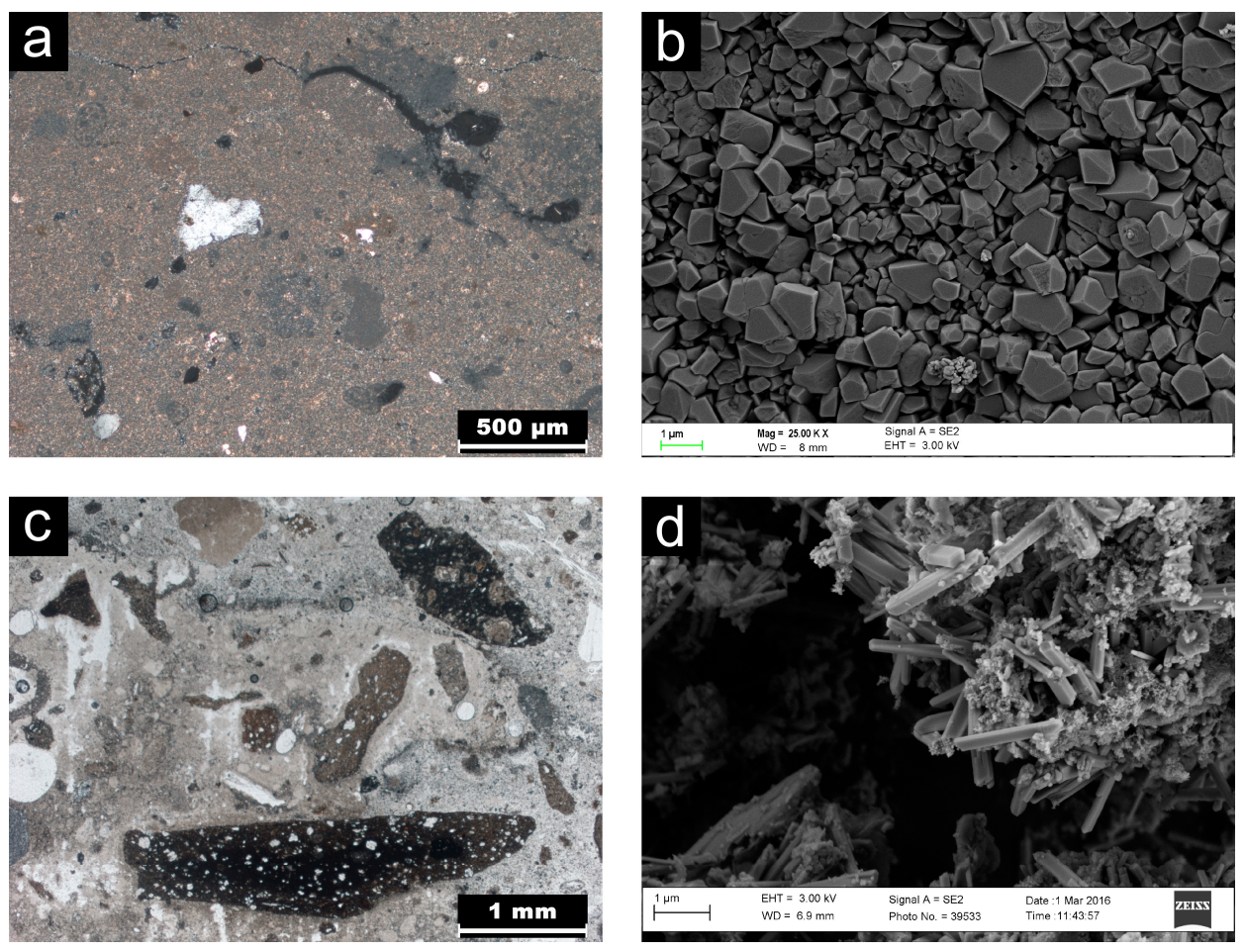

Figure 1. Examples of anthropogenic carbonates. (a) Thin section of Byzantine lime plaster from Shivta (Israel) seen in crossed-polarized light, note the micritic appearance of calcium carbonate crystals; (b) scanning electron microscope (SEM) image of calcite crystals in experimental lime plaster; (c) Thin section of medieval hydraulic mortar from Wilson's Arch (Israel) showing crushed pottery (cocciopesto) aggregates; (d) SEM image of acicular aragonite crystals in Iron Age ash from Megiddo (Israel). Detailed data about Shivta and Wilson's Arch in Toffolo et al. [23] and references therein; data about Megiddo in Toffolo et al. [21] and references therein. Figure $1 \mathrm{~b}$ is reproduced from Toffolo and Boaretto [49] with permission from Elsevier.

Equation (3) is particularly important for dating, as atmospheric $\mathrm{CO}_{2}$ contains ${ }^{14} \mathrm{C}$ and thus the final product bears the signature of the atmosphere at the time of the nucleation of pyrogenic $\mathrm{CaCO}_{3}[6]$. This makes archeological lime plaster a short-lived material, representing a specific point in time directly related to human activities. However, it should be noted that in some cases, the carbonation of plaster may take up to a few years to complete. This delay in the setting process is negligible for ${ }^{14} \mathrm{C}$ dating, unless aggregates of portlandite are preserved for tens or hundreds of years. These pose a major problem for the accuracy of measurements, as they can carbonate at a much later time compared to the first carbonation of the plaster and yield younger ages [23,52]. In addition, uneven burning of raw material can produce partially calcined or unburnt geologic fragments, which end up in hydrated 
lime. These components are ${ }^{14} \mathrm{C}$-free and therefore 'dilute' the isotopic signature of the pyrogenic binder, resulting in older ages [35].

Lime mortars are masonry binders obtained by mixing hydrated lime with an aggregate, usually sand-sized [1,3]. A carbonate aggregate comprised of geogenic calcite (e.g., limestone fragments) poses the same problem of unburnt and poorly burnt raw material, due to its old age $[9,10]$. Inert silicate aggregates, such as quartz sand, do not alter the ${ }^{14} \mathrm{C}$ content of the mortar because they are devoid of carbon $[7,8]$. On the contrary, reactive silicates like crushed ceramics (cocciopesto) and volcanic ash (pozzolana) trigger hydraulic reactions, which facilitate contamination [53] (Figure 1c).

In some cases, dolomite $\left[\mathrm{CaMg}\left(\mathrm{CO}_{3}\right)_{2}\right]$ was used for quicklime production instead of limestone, particularly in regions characterized by dolomite bedrock $[3,54]$. Besides being a less suitable construction material due to the slower reaction kinetics of $\mathrm{MgO}$ compared to $\mathrm{CaO}$, and the abovementioned problems caused by residual geogenic components, dolomitic quicklime is prone to the formation of $\mathrm{Mg}(\mathrm{OH})_{2}$ (brucite) [23], which over time evolves into $\mathrm{Mg}_{5}\left(\mathrm{CO}_{3}\right)_{4}(\mathrm{OH})_{2} \cdot 4 \mathrm{H}_{2} \mathrm{O}$ (hydromagnesite), a hydrous carbonate that incorporates older/younger carbon and thus hinders accurate dating $[29,30,33]$.

\subsection{Hydraulic Mortar}

Mixing hydrated lime with a reactive silicate aggregate such as volcanic ash and crushed ceramics promotes hydraulic reactions, which produce the calcium-silicate-hydrate (C-S-H) phases found in ancient cement $[1,3,55,56]$. In addition, there are minerals that contain carbonate groups, which are called layered double hydroxides (LDH). The most important are the LDHs in the hydrotalcite supergroup [57]. LDHs feature a layered structure that can incorporate ${ }^{14} \mathrm{C}$-free carbonate groups, and are known to exchange $\mathrm{CO}_{2}$ when exposed to the atmosphere, e.g., during sample preparation $[53,58,59]$. This process introduces modern carbon in the sample [20,34,39]. It has been recently shown that magnesium-silicate-hydrate (M-S-H) phases may nucleate together with LDHs when specific types of ceramic and ash are used as aggregates [60].

\subsection{Wood Ash}

Calcium oxalates are biogenic minerals produced by many woody plants, and usually come in the form of $\mathrm{CaC}_{2} \mathrm{O}_{4} \cdot \mathrm{H}_{2} \mathrm{O}$ (whewellite) or $\mathrm{CaC}_{2} \mathrm{O}_{4} \cdot 2 \mathrm{H}_{2} \mathrm{O}$ (weddellite) [2]. Upon burning wood at temperatures over $400{ }^{\circ} \mathrm{C}$, calcium oxalates release water and $\mathrm{CO}$ and decompose to $\mathrm{CaCO}_{3}[61,62]$, following this reaction:

$$
\mathrm{C}_{2} \mathrm{CaO}_{4} \cdot \mathrm{H}_{2} \mathrm{O} \stackrel{450^{\circ} \mathrm{C}}{\longrightarrow} \mathrm{CaCO}_{3}+\mathrm{H}_{2} \mathrm{O}+\mathrm{CO}
$$

The resulting ash pseudomorphs, which often exhibit the typical rhombohedral habit of oxalates, are the main component of ash and are always composed of calcite $[4,63]$. These are loosely termed here 'low-temperature ash'. When the firing temperature exceeds $600{ }^{\circ} \mathrm{C}$, pseudomorphs undergo further decomposition following equation (1), in a process similar to quicklime production. Instead of slaking with liquid water, hydrated lime is obtained from the reaction of $\mathrm{CaO}$ with atmospheric humidity after the fire is extinguished, as per equation (2). Following equation (3), hydrated lime subsequently carbonates as calcite, which is termed here 'high-temperature ash'. Calcite is the main polymorph in archeological high-temperature ash, although aragonite has been reported at several archeological sites, even as the dominant polymorph $[21,49,64,65]$ (Figure 1d).

Similar to lime plaster/mortar, high-temperature wood ash represents a short-lived material produced by specific human activities, and may be targeted for accurate dating. In theory, the same applies to low-temperature ash, because the carbon isotopic signature of calcium oxalates is biologically regulated and, in several plants, it matches the signature of cellulose. However, one should take into account the possibility of $\mathrm{CO}$ exchange between the decomposing calcium oxalates and the atmosphere during firing. This phenomenon may imply a variation in the ${ }^{14} \mathrm{C}$ content of oxalates, since its distribution in $\mathrm{CO}$ does not necessarily match values measured in $\mathrm{CO}_{2}$. Regev et al. [22] 
observed a shift to lighter isotopes in the $\delta^{13} \mathrm{C}$ value of modern calcitic ash compared to cellulose $\delta^{13} \mathrm{C}$ from the same plant, and ascribed it to the incorporation of $\mathrm{CO}$ derived from fossil fuel sources. While fossil fuels are not a concern in archeological times, it is possible that pre-industrial CO pMC (percentage of Modern Carbon) levels were higher compared to the ${ }^{14} \mathrm{C}$ concentration of the biosphere, and therefore $\mathrm{CO}$ exchange during combustion would have led to contamination. This process needs confirmation from controlled experiments including different fuels and burning conditions.

Since ash is a powdery substance, after burial it is easily mixed with the sedimentary matrix of the archeological site, which may include carbon contaminants. The main one is geogenic calcite, which originates from the decay of the local bedrock, aeolian transport (e.g., loess) or soil-forming processes (e.g., calcrete), and introduces contamination from ${ }^{14} \mathrm{C}$-free carbonates (geogenic) and/or from younger organic carbon (pedogenic).

\subsection{Dissolution and Recrystallization Process}

The preservation of anthropogenic carbonates in sediments and standing architectures depends mainly on two factors: water and $\mathrm{pH} . \mathrm{CaCO}_{3}$ is stable at $\mathrm{pH}$ values above 8 , but rapidly dissolves to $\mathrm{Ca}\left(\mathrm{HCO}_{3}\right)_{2}$ (calcium bicarbonate) when exposed to water rich in $\mathrm{H}_{2} \mathrm{CO}_{3}$ (carbonic acid) [2]. Rain water has a $\mathrm{pH}$ value of $\sim 5.7$, which may become more acidic when it incorporates acids produced by organic activity in sediments [66]. Acidic groundwater undersaturated with respect to calcite (or aragonite) induces the dissolution of anthropogenic carbonates buried in sediments [67], with wood ash being more affected due to its higher porosity compared to lime plaster and mortar. When groundwater is saturated and thus attains equilibrium, the dissolution of $\mathrm{CaCO}_{3}$ stops. Upon water evaporation, $\mathrm{Ca}\left(\mathrm{HCO}_{3}\right)_{2}$ precipitates as $\mathrm{CaCO}_{3}$, but the newly formed crystals are larger and more ordered at the atomic level compared to the original pyrogenic carbonate, following Ostwald's Rule of Stages [68]. More importantly, carbon exchange occurs in solution between pyrogenic $\mathrm{CaCO}_{3}$ and $\mathrm{H}_{2} \mathrm{CO}_{3}$, leading to contamination from older or younger environmental carbon, depending on its source. This aspect is particularly troublesome, as the presence of secondary calcite prevents ash and plaster from being accurately dated $[43,69]$. If acidic groundwater is constantly replaced, anthropogenic carbonates will dissolve completely. As a consequence, one might expect better preservation of anthropogenic carbonates at sites located in arid or temperate climate zones and on carbonate bedrock that can buffer sediments, whereas tropical climate and igneous bedrock favor dissolution.

Plasters and mortars in standing architectures are not exposed to groundwater, although it is known that rain and even humidity in air can induce the formation of secondary calcite [70-72]. In fact, the dissolution reaction takes place in extremely thin films of water at the scale of single crystals, which are often under $5 \mu \mathrm{m}$ in size in well-preserved pyrogenic binders [49,73]. Therefore, secondary calcium carbonate precipitation should also be expected in the interior of buildings.

\section{Characterization Methods}

As stated, anthropogenic carbonates are particularly sensitive to changes in the chemical environment, which lead to changes in the structure and isotopic composition of $\mathrm{CaCO}_{3}$ crystals, including loss of the initial ${ }^{14} \mathrm{C}$ signature in lime plaster/mortar and wood ash. In addition, other carbon-bearing secondary phases may form. These alterations can be monitored by looking at two proxies: degree of crystallinity and fractionation of ${ }^{13} \mathrm{C}$.

\subsection{Crystal Structure}

Calcite, the main $\mathrm{CaCO}_{3}$ polymorph found in wood ash and lime plaster/mortar, can be easily identified using X-ray diffraction (XRD) or any other method that addresses long-range atomic order in crystals. The same applies to aragonite, dolomite, brucite, hydromagnesite, portlandite, and LDHs, thus XRD is the best way to characterize crystalline phases in lime binders $[19,53,56,74,75]$. However, considering that ${ }^{14} \mathrm{C}$ dating of anthropogenic carbonates aims at targeting pyrogenic calcite and not its geogenic/diagenetic forms that often occur in the same sample, a complementary approach 
is required. In order to distinguish pyrogenic from geogenic/diagenetic calcite, which share the same composition, it is necessary to use methods that address its degree of short-range order and crystallinity. The latter is broadly defined here as the extent to which a crystal differs from perfect order in three dimensions at the molecular level, and it is referred to in terms of domain size and defects in the crystal structure. For instance, pyrogenic calcite exhibits lower crystallinity compared to its geogenic counterpart, as a consequence of the relatively rapid carbonation process of $\mathrm{Ca}(\mathrm{OH})_{2}$ as opposed to the slow nucleation of geologic crystals. Defects can be probed using vibrational spectroscopy [76,77].

Fourier transform infrared spectroscopy (FTIR) can identify pyrogenic calcite based on peak broadening. Regev et al. [78] and Poduska et al. [79] showed that calcite crystals formed by different mechanisms exhibit variations in peak broadening and intensity caused by distinct densities of structural defects. Using FTIR in transmission mode, they demonstrated that upon repeated grinding of the same $\mathrm{KBr}$ pellet, the intensity of the $v_{2}$ and $v_{4}$ absorptions of $\mathrm{CaCO}_{3}$, normalized to the intensity of the $v_{3}$ absorption, decreases and by plotting these ratios, trendlines ('grinding curves') specific to different types of $\mathrm{CaCO}_{3}$ may be drawn. Grinding curves allow detecting subtle differences in atomic order between pyrogenic and geogenic calcite, and the method was developed to identify human presence in the form of pyrotechnological activities. The same methodology has been applied to pyrogenic and biogenic aragonite [51,80] (Figure 2).
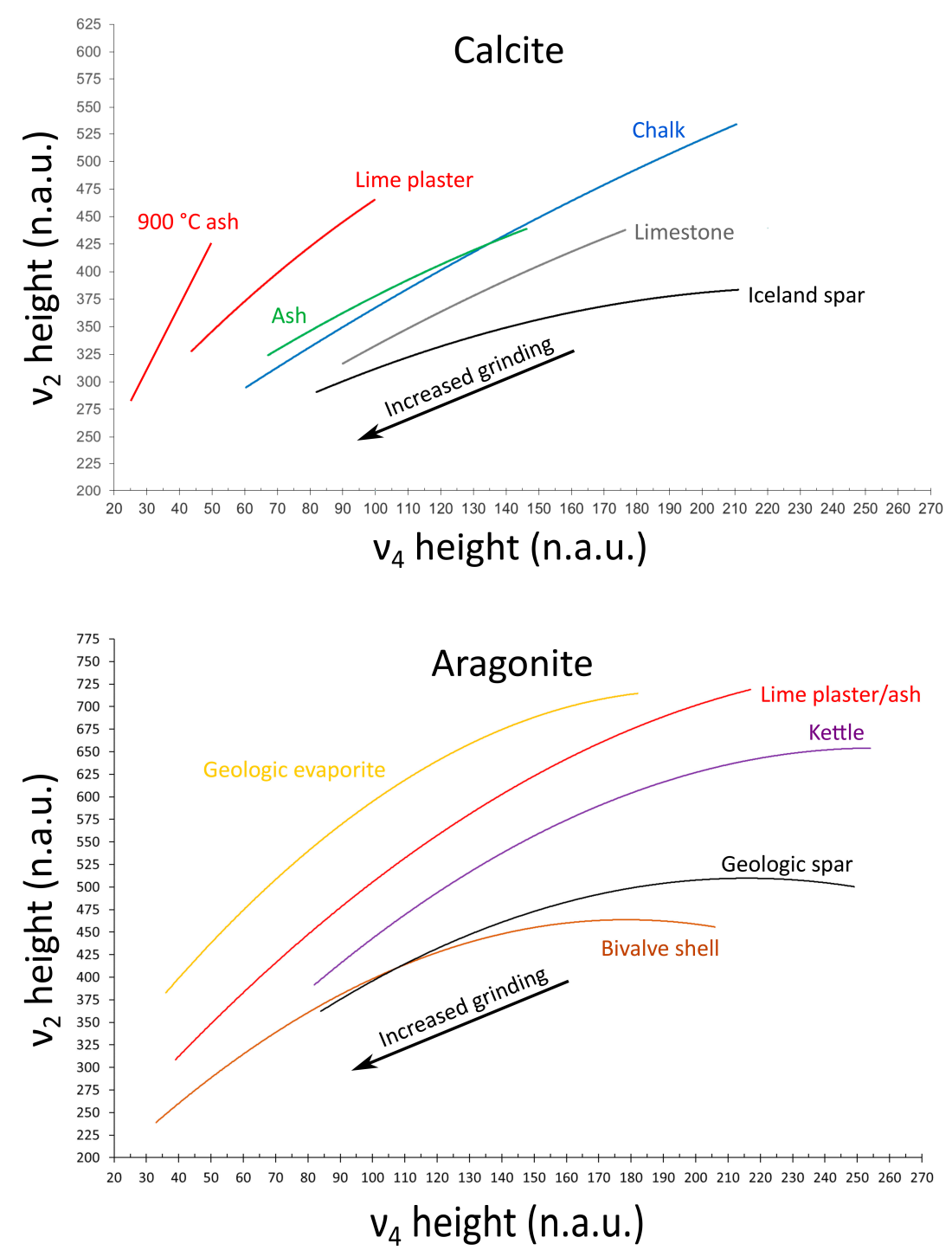

Figure 2. Grinding curves of calcite and aragonite (n.a.u.: normalized absorbance units). Each curve represents a different degree of local structural order and particle size based on calcite and aragonite 
standard materials of different origin, with lime plaster and geologic evaporite being the least ordered and spar standards the most ordered. The shape of each curve is determined by changes in particle size, whereas the offset depends on the degree of local structural order. The top chart is reproduced after Regev et al. [78], with permission from Elsevier. The bottom chart is modified after Toffolo et al. [51].

The normalized $v_{2}$ and $v_{4}$ intensities of standard materials that provide the framework for the grinding curve method cannot be used as reference for the same peaks in spectra of archeological samples collected in attenuated total reflectance mode (ATR). ATR peaks exhibit different line and relative intensity profiles compared to peaks obtained from homogenized powders dispersed in a $\mathrm{KBr}$ pellet in transmission mode [81]. In addition, the standard materials of the grinding curve method are checked against an 'ideal' transmission spectrum of $\mathrm{CaCO}_{3}$ obtained using quantum chemical calculations [79]. The latter are not available for ATR spectra. Therefore, there is no relation between ATR spectra of archeological samples and grinding curves obtained in transmission mode (including the $v_{2} / v_{4}$ method [76]), and comparisons will produce misleading interpretations about the state of preservation of samples.

Spatial information regarding the distribution of calcites characterized by different degrees of atomic order can be obtained through the analysis of thin sections [82]. Most diagenetic calcite, which forms mainly sparitic crystals, can be easily differentiated from pyrogenic calcite, which is micritic $[43,83]$. Other polymorphs, such as aragonite, cannot be identified with certainty and thus require the application of FTIR spectroscopy using a microscope. In reflectance mode, this method has shown potential in distinguishing pyrogenic and geogenic/diagenetic calcite based on the position and width of the $v_{3}$ absorption in both lime plaster/mortar and ash $[23,43,84,85]$.

Another effective method used to distinguish pyrogenic calcite from its geogenic form is cathodoluminescence (CL), first applied to mortar screening by Heinemeier et al. [12]. In most geogenic carbonates, $\mathrm{Mn}^{2+}$ substituting for $\mathrm{Ca}^{2+}$ in the calcite crystal lattice produces orange $\mathrm{CL}$ when the crystal is irradiated with an electron beam. Based on this phenomenon, fragments of geogenic calcite have been identified in lime binders selected for dating [14]. A more recent application to anthropogenic carbonates features a CL detector attached to a scanning electron microscope (SEM-CL) [86]. This instrument setup allows high-resolution analysis of powdered samples pressed into pellets, as well as thin sections and polished casts. Its advantages lie in the possibility to analyze extremely small areas, in the order of a few $\mathrm{nm}$, using wavelength-resolved spectra, and to identify minor amounts of contamination that are not visible by eye through an optical microscope. Toffolo et al. [86,87] showed that experimental pyrogenic binders exhibit blue CL due to the absence or low occurrence of $\mathrm{MnCO}_{3}$ sites, whereas geogenic calcites exhibit orange $\mathrm{CL}$, and the same trend is verified in archeological plasters that are well preserved according to FTIR (Figure 3).

\subsection{Isotopic Signature}

Several studies have shown that pyrogenic $\mathrm{CaCO}_{3}$ fractionates carbon and oxygen isotopes upon carbonation, in both lime plaster/mortar and high-temperature ash, resulting in a specific range of $\delta^{13} \mathrm{C}$ values for pyrogenic calcite carbonated at ambient conditions [22,63,88-91]. This phenomenon has been used to identify a window of $\delta^{13} \mathrm{C}$ values that can be used as a proxy for good preservation of pyrogenic calcite, based on the notion that mixing with geogenic and diagenetic carbonates shifts the ${ }^{13} \mathrm{C}$ to heavier values. It has been observed that values between -16 and $-25 \%$ o should reflect pristine pyrogenic calcite, as shown by experimental samples produced at different calcination temperatures $[40,63,92]$. However, the application of this method to bulk archeological plaster/mortar requires caution, as the intact binder should be separated from contaminants for accurate analysis, especially in poorly preserved or highly-contaminated samples [35]. 

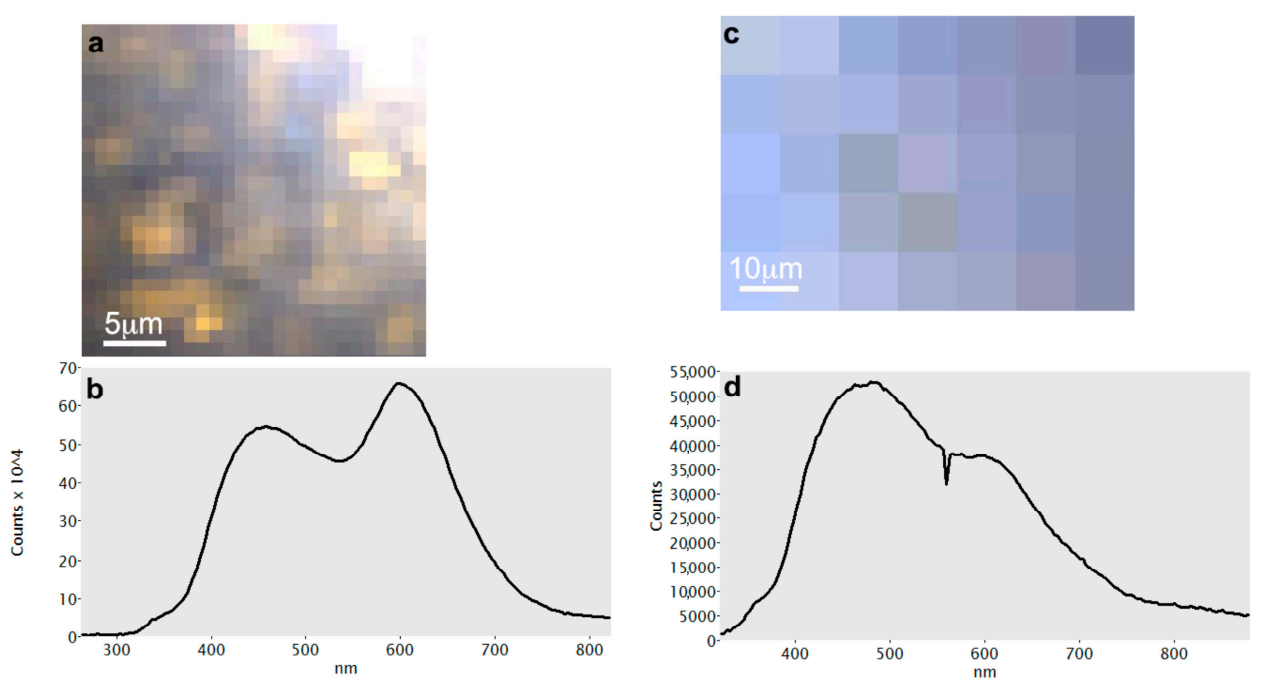

Figure 3. SEM-CL spectra of calcite, modified after Toffolo et al. [87]. (a) Spectrum imaging map of chalk showing emission colors (each pixel corresponds to one measurement); (b) Representative CL spectrum of chalk showing high peak at $\sim 610 \mathrm{~nm}$ caused by $\mathrm{Mn}^{2+} ;$ (c) Spectrum imaging map of lime plaster obtained from chalk in $(\mathbf{a}, \mathbf{b})$; (d) Representative CL spectrum of lime plaster showing shoulder at $\sim 610 \mathrm{~nm}$ caused by displacement of $\mathrm{Mn}^{2+}$.

\section{Assessing the State of Preservation}

Recently, Urbanová et al. [31] rightly defined the 'dateable fraction' in lime mortars as "the separated fine fraction of anthropogenic carbonate that has been experimentally screened for the absence of secondary carbonate, geogenic carbonate, and spurious $\mathrm{CO}_{2}$-containing phases". This definition implies that samples should be characterized in order to identify the target fraction and treated to isolate the latter for carbon recovery. In addition, the definition implies that the target fraction can be differentiated with certainty from all contaminants based on one or more of its basic properties, but does not actually provide a description of the 'dateable fraction' itself. This is not an easy task, especially when pyrogenic calcite is mixed with secondary calcite produced by diagenetic processes. Here, the potential of the degree of short-range atomic order in calcite crystals is examined using FTIR and SEM-CL spectroscopy.

\subsection{Initial Screening}

A first glimpse of the degree of preservation of anthropogenic carbonates can be obtained using transmission FTIR on bulk samples. If pyrogenic calcite in binders is overall intact, its normalized $v_{2}$ and $v_{4}$ intensities will fall on or close to the experimental lime plaster trendline. On the contrary, if substantial dissolution and recrystallization took place, values will match the trendline of wood ash, or even limestone, as a consequence of Ostwald's Rule of Stages. The occurrence of geogenic aggregates leads to the same outcome. In such cases, dating should be avoided. It should be noted that transmission FTIR probes a mixture of crystals, and therefore the resulting calcite spectrum may represent a mixed signal (most geogenic and diagenetic components can be identified in thin section). Bearing this in mind, if the normalized $v_{2}$ and $v_{4}$ intensities are very close to the experimental plaster curve, one can safely assume that most of the pyrogenic calcite crystals are well preserved, and that only minor amounts of fine geogenic/diagenetic components may be dispersed in lime binders. Clearly, several different areas of the sample should be analyzed to track variability. Similarly, if low-temperature ash is characterized by structural order typical of limestone, then recrystallization has taken place.

This approach has been implemented by Poduska et al. [43] in the study of Pre-Pottery Neolithic lime plaster floors from Yiftahel (Israel). The top-coat layers exhibited the lowest degree of atomic order (similar to experimental plaster) and were thus targeted for carbon recovery, which was performed by 
dissolving the entire layer in phosphoric acid. The measured pMC fell close to the pMC range of the site (based on organic materials) and highlighted the occurrence of residual atmospheric/environmental contamination from secondary calcite (Figure 4). With regard to ash, Regev et al. [22] showed that calcite grains ranging between $1 \mathrm{~mm}$ and $20 \mu \mathrm{m}$ from a Natufian ash layer at Hayonim Cave (Israel) matched the grinding curve of geogenic calcite. The pMC of this fraction yielded older apparent ages due to the contribution of 'dead carbon'.

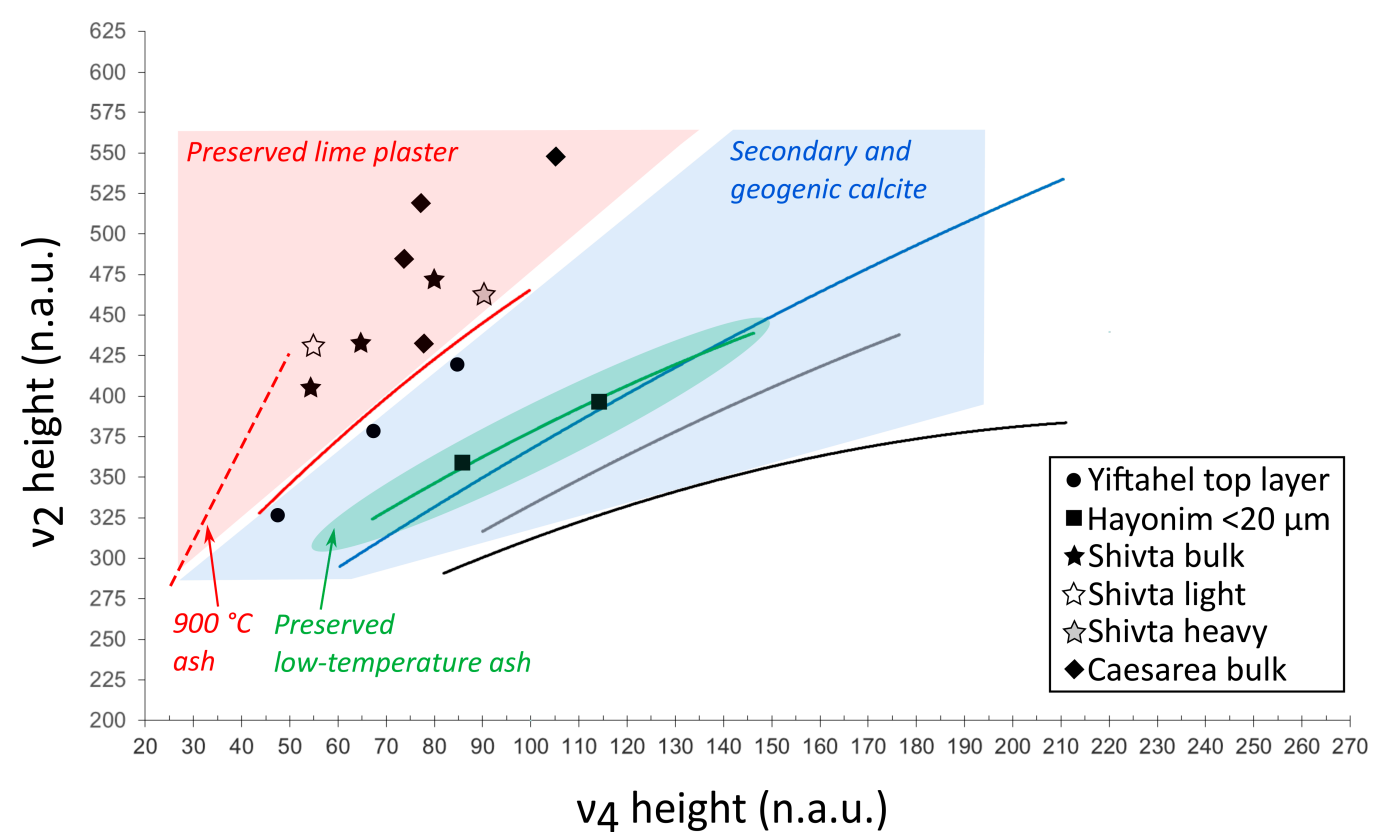

Figure 4. Grinding curves of calcite, showing location of archeological samples (n.a.u.: normalized absorbance untis). Trendlines reproduced after Regev et al. [78] with permission from Elsevier; Yiftahel data points modified after Poduska et al. [43]; Hayonim data points modified after Regev et al. [22]; Shivta data points modified after Toffolo et al. [23]; Caesarea data points modified after Asscher et al. [44]. The $v_{2}$ and $v_{4}$ normalized heights of calcite in archeological samples can be plotted in this chart to determine their degree of preservation.

Toffolo et al. [23] observed that a Byzantine aerial lime plaster from Shivta (Israel) exhibited pyrogenic calcite considerably less ordered than calcite in experimental lime plaster, and rather resembled high-temperature ash obtained by re-burning at $900{ }^{\circ} \mathrm{C}$ low-temperature wood ash [78] (Figure 4). While the sample is suitable for dating, this fact gives the false impression that experimental lime plaster is less preserved than the archeological plaster, and calls for a better understanding of the basic properties of pyrogenic $\mathrm{CaCO}_{3}$. It is known that $\mathrm{CaO}$ crystallite size and carbonation temperature play a major role in the development of pyrogenic calcite crystals [93]. This means that a less ordered reference plaster is required, considering that the method was initially developed to distinguish pyrogenic from geogenic calcite. The reference experimental plaster used by Regev et al. [78] was obtained by burning limestone in a bonfire; controlled firing and carbonation conditions may help reducing the atomic order of calcite crystals.

When pyrogenic aragonite is the main polymorph, it should be distinguished from the biogenic form (e.g., shell aggregate in mortars). The grinding curve method has shown that this is possible in lime plasters comprised of both aragonite and calcite, as in the case of Pre-Pottery Neolithic floor plasters at Motza (Israel), and in aragonitic ash from Bronze Age levels at Tell es-Safi/Gath (Israel) and Iron Age levels at Megiddo [51] (Figure 5). The latter has been accurately dated based on its primary occurrence, since normally it does not precipitate from calcium bicarbonate. Secondary aragonite has not been reported yet in anthropogenic carbonates, thus diagenetic phases may be confined to secondary calcite, and aragonite targeted for dating [21]. 


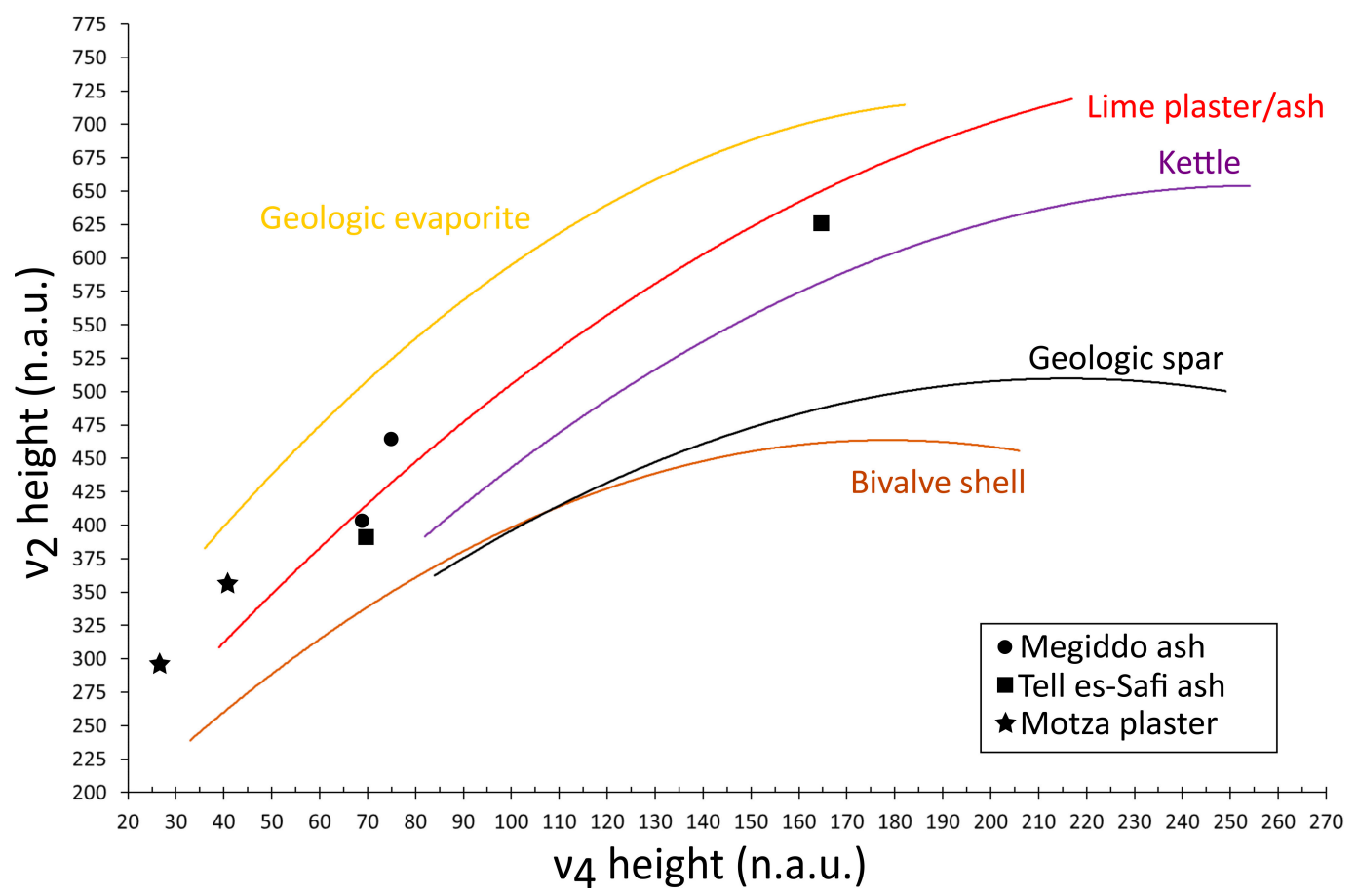

Figure 5. Grinding curves of aragonite, showing location of archeological samples, modified after Toffolo et al. [51] (n.a.u.: normalized absorbance units). Data points from Toffolo et al. [51]. The $v_{2}$ and $v_{4}$ normalized heights of aragonite in archeological samples can be plotted in this chart to determine their mechanism of formation.

In the case of hydraulic mortars, Asscher et al. [44] showed that there is a negative correlation between the state of preservation of pyrogenic calcite and the occurrence of hydraulic phases in mortars from Caesarea Maritima (Israel), based on FTIR and XRD. Samples characterized by calcite showing poor atomic order according to the grinding curve method feature a non-reactive silicate aggregate, such as quartz or smectites (Figure 4). Interestingly, as observed at Shivta, some of the samples fall far above the experimental plaster trendline. In contrast, mortars rich in hydraulic phases derived from volcanic ash, such as LDHs, consistently present more ordered calcite, indicating that the nucleation of the former affects the degree of atomic order of the latter, which should be avoided for accurate ${ }^{14} \mathrm{C}$ dating.

\subsection{Purified Fractions}

Once well-preserved pyrogenic calcite has been identified based on its degree of local structural order, it is necessary to separate it from other phases that may occur in the sample in order to avoid contamination during carbon recovery, either by dry sieving [14], by settling in a water column [20], by density in a heavy liquid [23], or by thermal decomposition of the hydraulic phases [19]. These methods might not always remove all contaminants; therefore, the quality of the purified sample should be verified at the end of the process. Assessments should be performed at the microscopic scale, given that even a small amount of contamination can produce significant offsets in the pMC $[23,94]$. After a purified fraction has been obtained, carbon is recovered as $\mathrm{CO}_{2}$ by acid hydrolysis [14] or thermal decomposition of calcite [23].

Most contaminants, such as dolomite, hydromagnesite, portlandite, and LDHs, can be easily detected using XRD and may be removed by repeating the purification procedure $[20,29,33,34]$. Carbonation of portlandite during sample treatment may be overcome by working in a controlled, $\mathrm{CO}_{2}$-free atmosphere (e.g., argon). At this stage, the main problem is the identification of geogenic and secondary calcite. While geogenic components are often successfully removed in water columns and by density, secondary calcite may exhibit physical properties similar to those of pyrogenic calcite [42]. 
Ricci et al. [19] developed an effective method that allows removal of hydraulic phases via thermal decomposition of a purified fraction obtained by settling powdered lime binder in a water column. This method was applied to medieval mortars from Cannero (Italy). LDHs decompose at $550{ }^{\circ} \mathrm{C}$ in vacuum, and the leftover is dissolved in phosphoric acid without further exposure to air. A shortcoming of this approach is that small amounts of secondary calcite in the sample cannot be detected once the sample is sealed in vacuum. However, the suspended fraction recovered by settling can be tested using FTIR and SEM-CL before thermal decomposition. Asscher et al. [44] analyzed purified fractions from Cannero and found that some of them where consistent with poorly ordered calcite in experimental plaster.

Toffolo et al. [23] used transmission FTIR to characterize light fractions obtained by centrifugation of sieved lime binders in a heavy liquid, and showed that they are less ordered than the heavy fractions, therefore suitable for accurate dating (Figure 4). The fact that both light and heavy fractions of the Shivta plaster are less ordered than the experimental plaster reference makes one doubt as to whether some secondary calcite is responsible for the difference in atomic order between the two, taking into account the observed shifts towards higher pMC values (i.e., dates younger than expected) in $\mathrm{CO}_{2}$ aliquots obtained by decomposing light fractions at $500^{\circ} \mathrm{C}$ (Figure 5). The authors postulated that using particles larger than $50 \mu \mathrm{m}$ in some of the experiments introduced contamination, since secondary crystals tend to be larger than pyrogenic ones. Contamination due to geogenic calcite appears less likely because the pMC did not shift to lower values. Analysis of the light fractions using SEM-CL has shown that most of the sample exhibits the blue CL characteristic of pyrogenic calcite. A few areas, however, featured orange CL that could be consistent with diagenetic alteration [95]. This aspect should be further investigated through the analysis of micritic and sparitic secondary crystals in archeological samples of different age. If confirmed, a more accurate carbon recovery procedure, based either on acid hydrolysis or thermal decomposition, is required in order to avoid the contribution of secondary calcite.

Promising results have been obtained with ash. Regev et al. [22] dry-sieved the Natufian ash layer from Hayonim Cave and recovered the fraction smaller than $20 \mu \mathrm{m}$ (the size range of ash pseudomorphs), which matched the grinding curve of experimental low-temperature ash (Figure 4). The pMC of that fraction was consistent with the pMC range of the Natufian period, although the absence of a short-lived, charred control sample from the same layer may question the accuracy of the measurement. Nonetheless, charcoal from a lower layer within the same excavation locus yielded an older age. Toffolo et al. [21] separated pyrogenic aragonite from other phases in an Iron Age ash layer at Megiddo (Israel) using centrifugation in a heavy liquid. This purified fraction was then thermally decomposed and the $\mathrm{CO}_{2}$ evolved at $550{ }^{\circ} \mathrm{C}$ yielded a pMC consistent with charred seeds recovered in the same combustion feature and elsewhere within the same stratigraphic unit. It thus seems that regardless of the method used to isolate the target fraction (dry sieving, density), pyrogenic calcite and aragonite can be effectively recovered from ash due to their occurrence as single crystals rather than intergrown minerals in a binder (Figure 1). This, of course, is entirely dependent on the degree of preservation of sediments.

\subsection{Defining the Benchmark}

Adding to the definition of 'dateable fraction' given by Urbanová et al. [31], it is possible to state that $\mathrm{CaCO}_{3}$ in this fraction should exhibit the same degree of local structural order of pyrogenic $\mathrm{CaCO}_{3}$ in experimental samples of lime plaster and ash. The examples described above have shown that FTIR spectroscopy is an effective method that can distinguish pyrogenic calcite from geogenic and secondary calcite, and pyrogenic aragonite from other forms. The initial screening allows discarding heavily recrystallized samples. FTIR can identify other contaminants such as portlandite, dolomite and hydromagnesite; XRD is instead required for a detailed characterization of hydraulic phases.

FTIR can identify pyrogenic $\mathrm{CaCO}_{3}$ in purified fractions as well. However, at present there seems to be no clear-cut distinction with secondary calcite when the latter appears to be only slightly 
recrystallized and presents an infrared signature similar to that of experimental plaster. SEM-CL aids in the correct assessment of the degree of preservation of the purified fraction, but does not solve the problem of removing the contribution of secondary crystals during carbon recovery. Thermogravimetric analysis could provide temperature thresholds for the thermal decomposition of secondary calcite as opposed to pyrogenic calcite, as it is known that the latter requires a lower temperature for the breakdown of carbonate groups [96]. The different phases could be characterized by looking at their $\delta^{13} \mathrm{C}$ signature, following previous experimental studies of lime binders [40,63,92]. Toffolo et al. [23] envisaged the application of laser-ablation for accurate carbon recovery and direct AMS dating of lime binders, especially those characterized by large quantities of dispersed contaminants. This method, which has been successfully applied to speleothems [97], would overcome the necessity to isolate the target fraction by using physical means. At present, all these aspects require further investigation.

\section{Conclusions}

Accurate ${ }^{14} \mathrm{C}$ dating of anthropogenic carbonates is feasible for lime binders and wood ash, provided that contaminants are removed and that the pyrogenic $\mathrm{CaCO}_{3}$ targeted for carbon recovery is well preserved. In this review, it was proposed to use the degree of local structural order of $\mathrm{CaCO}_{3}$ crystals as a criterion for the selection of suitable samples. This can be assessed at the molecular level using FTIR and SEM-CL spectroscopy in both bulk samples and purified fractions, and should match the degree of atomic order of experimental pyrogenic materials. One major problem that remains to be solved is the contribution of secondary calcite when it is only slightly recrystallized compared to the poorly ordered crystals of the pristine pyrogenic fraction. Reference standard materials produced under controlled conditions may help improve the FTIR grinding curve method. In addition, refined carbon recovery procedures may provide better means of identifying and excluding $\mathrm{CO}_{2}$ evolved from secondary calcite.

Funding: This study was funded by a grant from IdEx Bordeaux (grant n. ANR-10-IDEX-03-02 to Michael Toffolo). Acknowledgments: I wish to thank Lior Regev for help in acquiring Figure $1 \mathrm{~d}$ and the Reviewers for their comments.

Conflicts of Interest: The author declares no conflict of interest. The funders had no role in the design of the study; in the collection, analyses, or interpretation of data; in the writing of the manuscript, or in the decision to publish the results.

\section{References}

1. Artioli, G. Scientific Methods and Cultural Heritage: An Introduction to the Application of Materials Science to Archaeometry and Conservation Science; Oxford University Press: Oxford, UK, 2010.

2. Weiner, S. Microarchaeology. Beyond the Visible Archeological Record; Cambridge University Press: New York, NY, USA, 2010.

3. Artioli, G.; Secco, M.; Addis, A. The Vitruvian legacy: Mortars and binders before and after the Roman world. EMU Notes Mineral. 2019, 20, 151-202.

4. Canti, M.G. Aspects of the chemical and microscopic characteristics of plant ashes found in archeological soils. Catena 2003, 54, 339-361. [CrossRef]

5. Sandgathe, D.M.; Berna, F. Fire and the Genus Homo. Curr. Anthropol. 2017, 58, 165-174. [CrossRef]

6. Boaretto, E.; Poduska, K.M. Materials Science Challenges in Radiocarbon Dating: The Case of Archeological Plasters. J. Miner. Met. Mater. Soc. (TMS) 2013, 65, 481-488. [CrossRef]

7. Labeyrie, J.; Delibrias, G. Dating of Old Mortars by the Carbon-14 Method. Nature 1964, 201, 742. [CrossRef]

8. Delibrias, G.; Labeyrie, J. The dating of mortars by the carbon-14 method. In Proceedings of the 6th International Conference on Radiocarbon and Tritium Dating, Pullman, WA, USA, 7-11 June 1965; pp. 344-347.

9. Stuiver, M.; Smith, C.S. Radiocarbon dating of ancient mortar and plaster. In Proceedings of the 6th International Conference on Radiocarbon and Tritium Dating, Pullman, WA, USA, 7-11 June 1965; pp. 338-343.

10. Baxter, M.S.; Walton, A. Radiocarbon dating of mortars. Nature 1970, 225, 937-938. [CrossRef] 
11. Folk, R.L.; Valastro, S. Successful Technique for Dating of Lime Mortar by Carbon-14. J. Field Archaeol. 1976, 3, 203-208. [CrossRef]

12. Heinemeier, J.; Jungner, H.; Lindroos, A.; Ringbom, Å.; von Konow, T.; Rud, N. AMS ${ }^{14}$ C dating of lime mortar. Nucl. Instrum. Methods Phys. Res. Sect. B Beam Interact. Mater. At. 1997, 123, 487-495. [CrossRef]

13. Heinemeier, J.; Ringbom, A.; Lindroos, A.; Sveinbjörndóttir, Á. Successful AMS ${ }^{14} \mathrm{C}$ dating of non-hydraulic lime mortars from the medieval churches of the Åland Islands, Finland. Radiocarbon 2010, 52, 171-204. [CrossRef]

14. Lindroos, A.; Heinemeier, J.; Ringbom, Å.; Braskén, M.; Sveinbjörndóttir, Á. Mortar dating using AMS ${ }^{14} \mathrm{C}$ and sequential dissolution: Examples from medieval, non-hydraulic lime mortars from the Åland Islands, SW Finland. Radiocarbon 2007, 49, 47-67. [CrossRef]

15. van Strydonck, M.J.Y.; van der Borg, K.; de Jong, A.F.M.; Keppens, E. Radiocarbon dating of lime fractions and organic material from buildings. Radiocarbon 1992, 34, 873-879. [CrossRef]

16. Nawrocka, D.; Michniewicz, J.; Pawlyta, J.; Pazdur, A. Application of radiocarbon method for dating of lime mortars. Geochronometria 2005, 24, 109-115.

17. Pesce, G.; Quarta, G.; Calcagnile, L.; D’Elia, M.; Cavaciocchi, P.; Lastrico, C.; Guastella, R. Radiocarbon dating of lumps from aerial lime mortars and plasters: Methodological issues and results from San Nicolò of Capodimonte church (Camogli, Genoa, Italy). Radiocarbon 2009, 51, 867-872. [CrossRef]

18. Sonninen, E.; Jungner, H. An improvement in preparation of mortar for radiocarbon dating. Radiocarbon 2001, 43, 271-273. [CrossRef]

19. Ricci, G.; Secco, M.; Marzaioli, F.; Terrasi, F.; Passariello, I.; Addis, A.; Lampugnani, P.; Artioli, G. The Cannero Castle (Italy): Development of radiocarbon dating methodologies in the framework of the layered double hydroxide mortars. Radiocarbon 2020, 62, 617-631. [CrossRef]

20. Addis, A.; Secco, M.; Marzaioli, F.; Artioli, G.; Chavarria Arnau, A.; Passariello, I.; Terrasi, F.; Brogiolo, G.P. Selecting the most reliable ${ }^{14} \mathrm{C}$ dating material inside mortars: The origin of the Padua Cathedral. Radiocarbon 2019, 61, 375-393. [CrossRef]

21. Toffolo, M.B.; Regev, L.; Mintz, E.; Poduska, K.M.; Shahack-Gross, R.; Berthold, C.; Miller, C.E.; Boaretto, E. Accurate radiocarbon dating of archeological ash using pyrogenic aragonite. Radiocarbon 2017, 59, 231-249. [CrossRef]

22. Regev, L.; Eckmeier, E.; Mintz, E.; Weiner, S.; Boaretto, E. Radiocarbon concentrations of wood ash calcite: Potential for dating. Radiocarbon 2011, 53, 117-127. [CrossRef]

23. Toffolo, M.B.; Regev, L.; Mintz, E.; Kaplan-Ashiri, I.; Berna, F.; Dubernet, S.; Xin, Y.; Regev, J.; Boaretto, E. Structural characterization and thermal decomposition of lime binders allow accurate radiocarbon age determinations of aerial lime plaster. Radiocarbon 2020, 62, 633-655. [CrossRef]

24. Marzaioli, F.; Lubritto, C.; Nonni, S.; Passariello, I.; Capano, M.; Terrasi, F. Mortar Radiocarbon Dating: Preliminary Accuracy Evaluation of a Novel Methodology. Anal. Chem. 2011, 83, 2038-2045. [CrossRef]

25. Michalska, D.; Czernik, J. Carbonates in leaching reactions in context of ${ }^{14} \mathrm{C}$ dating. Nucl. Instrum. Methods Phys. Res. Sect. B Beam Interact. Mater. At. 2015, 361, 431-439. [CrossRef]

26. Ortega, L.A.; Zuluaga, M.C.; Alonso-Olazabal, A.; Murelaga, X.; Insausti, M.; Ibañez-Exteberria, A. Historic lime-mortar ${ }^{14} \mathrm{C}$ dating of Santa Maria La Real (Zarautz, northern Spain): Extraction of suitable grain size for reliable ${ }^{14} \mathrm{C}$ dating. Radiocarbon 2012, 54, 23-36. [CrossRef]

27. van Strydonck, M. Radiocarbon dating of lime mortars: A historic overview. In Proceedings of the 4th Historic Mortars Conference, Santorini, Greece, 10-12 October 2016; pp. 648-655.

28. Marzaioli, F.; Nonni, S.; Passariello, I.; Capano, M.; Ricci, P.; Lubritto, C.; De Cesare, N.; Eramo, G.; Quiros Castillo, J.A.; Terrasi, F. Accelerator mass spectrometry ${ }^{14} \mathrm{C}$ dating of lime mortars: Methodological aspects and field study applications at CIRCE (Italy). Nucl. Instrum. Methods Phys. Res. Sect. B Beam Interact. Mater. At. 2013, 294, 246-251. [CrossRef]

29. Hayen, R.; Van Strydonck, M.; Fontaine, L.; Boudin, M.; Lindroos, A.; Heinemeier, J.; Ringbom, Å.; Michalska, D.; Hajdas, I.; Hueglin, S.; et al. Mortar dating methodology: Assessing recurrent issues and needs for future research. Radiocarbon 2017, 59, 1859-1871. [CrossRef]

30. Hajdas, I.; Lindroos, A.; Heinemeier, J.; Ringbom, Å.; Marzaioli, F.; Terrasi, F.; Passariello, I.; Capano, M.; Artioli, G.; Addis, A.; et al. Preparation and dating of mortar samples-Mortar Dating Intercomparison Study (MODIS). Radiocarbon 2017, 59, 1-14. [CrossRef] 
31. Urbanová, P.; Boaretto, E.; Artioli, G. The state-of-the-art of dating techniques applied to ancient mortars and binders: A review. Radiocarbon 2020, 62, 503-525. [CrossRef]

32. Michalska, D. Influence of different pretreatments on mortar dating results. Nucl. Instrum. Methods Phys. Res. Sect. B Beam Interact. Mater. At. 2019, 456, 236-246. [CrossRef]

33. Hayen, R.; Van Strydonck, M.; Boaretto, E.; Lindroos, A.; Heinemeier, J.; Ringbom, Å.; Hueglin, S.; Michalska, D.; Hajdas, I.; Marzaioli, F.; et al. Analysis and characterisation of historic mortars for aboslute dating. In Proceedings of the 4th Historic Mortars Conference, Santorini, Greece, 10-12 October 2016; pp. 656-664.

34. Addis, A.; Secco, M.; Preto, N.; Marzaioli, F.; Passariello, I.; Brogiolo, G.P.; Chavarria Arnau, A.; Artioli, G.; Terrasi, F. New strategies for radiocarbon dating of mortars: Multi-step purification of the lime binder. In Proceedings of the 4th Historic Mortars Conference, Santorini, Greece, 10-12 October 2016; pp. 665-672.

35. Murakami, T.; Hodgins, G.; Simon, A.W. Characterization of lime carbonates in plasters from Teotihuacan, Mexico: Preliminary results of cathodoluminescence and carbon isotope analyses. J. Archeol. Sci. 2013, 40, 960-970. [CrossRef]

36. Nonni, S.; Marzaioli, F.; Mignardi, S.; Passariello, I.; Capano, M.; Terrasi, F. Radiocarbon dating of mortars with a pozzolana aggregate using the Cryo2SoniC protocol to isolate the binder. Radiocarbon 2018, 60, 617-637. [CrossRef]

37. Al-Bashaireh, K.; Hodgins, G.W. Lime mortar and plaster: A radiocarbon dating tool for dating Nabatean structures in Petra, Jordan. Radiocarbon 2012, 54, 905-914. [CrossRef]

38. Lindroos, A.; Regev, L.; Oinonen, M.; Ringbom, Å.; Heinemeier, J. ${ }^{14} \mathrm{C}$ dating of fire-damaged mortars from medieval Finland. Radiocarbon 2012, 54, 915-932. [CrossRef]

39. Ponce-Antón, G.; Ortega, L.A.; Zuluaga, M.C.; Alonso-Olazabal, A.; Solaun, J.L. Hydrotalcite and Hydrocalumite in Mortar Binders from the Medieval Castle of Portilla (Álava, North Spain): Accurate Mineralogical Control to Achieve More Reliable Chronological Ages. Minerals 2018, 8, 326. [CrossRef]

40. Marzaioli, F.; Terrasi, F.; Passariello, I.; D’Onofrio, A.; Di Rienzo, B.; Stellato, L.; Artioli, G.; Addis, A.; Secco, M.; Nonni, S.; et al. Investigation of pre-screening and cost-effective tools for mortar dating at CIRCE and CIRCe: Data from the usage of ${ }^{13} \mathrm{C}$ in the framework of synthetic samples. Archeol. dell'Architettura 2019, XXIV, 73-79.

41. Lubritto, C.; Ricci, P.; Germinario, C.; Izzo, F.; Mercurio, M.; Langella, A.; Salvatierra Cuenca, V.; Montilla Torres, I.; Fedi, M.; Grifa, C. Radiocarbon dating of mortars: Contamination effects and sample characterisation. The case-study of Andalusian medieval castles (Jaén, Spain). Measurement 2018, 118, 362-371. [CrossRef]

42. Ponce-Antón, G.; Lindroos, A.; Ringbom, Å.; Ortega, L.A.; Zuluaga, M.C.; Hajdas, I.; Olsen, J.; Mauleon, J.A. Comparison of sample preparation procedures for mortar radiocarbon dating. Case study of Irulegi Castle (Navarre, Spain). Quat. Geochronol. 2020, 60, 101110. [CrossRef]

43. Poduska, K.M.; Regev, L.; Berna, F.; Mintz, E.; Milevski, I.; Khalaily, H.; Weiner, S.; Boaretto, E. Plaster characterization at the PPNB site of Yiftahel (Israel) including the use of ${ }^{14} \mathrm{C}$ : Implications for plaster production, preservation, and dating. Radiocarbon 2012, 54, 887-896. [CrossRef]

44. Asscher, Y.; van Zuiden, A.; Elimelech, C.; Gendelman, P.; 'Ad, U.; Sharvit, J.; Secco, M.; Ricci, G.; Artioli, G. Prescreening hydraulic lime-binders for disordered calcite in Caesarea Maritima: Characterizing the chemical environment using FTIR. Radiocarbon 2020, 62, 527-543. [CrossRef]

45. Yizhaq, M.; Mintz, G.; Cohen, I.; Khalaily, H.; Weiner, S.; Boaretto, E. Quality controlled radiocarbon dating of bones and charcoal from the early Pre-Pottery Neolitic B (PPNB) of Motza (Israel). Radiocarbon 2005, 47, 193-206. [CrossRef]

46. DeNiro, M.J.; Weiner, S. Chemical, enzymatic and spectroscopic characterization of "collagen" and other organic fractions from prehistoric bones. Geochim. Cosmochim. Acta 1988, 52, 2197-2206. [CrossRef]

47. Alon, D.; Mintz, G.; Cohen, I.; Weiner, S.; Boaretto, E. The use of Raman spectroscopy to monitor the removal of humic substances from charcoal: Quality control for ${ }^{14} \mathrm{C}$ dating of charcoal. Radiocarbon 2002, 44, 1-11. [CrossRef]

48. Boynton, R.S. Chemistry and Technology of Lime and Limestone; John Wiley \& Sons, Inc.: New York, NY, USA, 1980.

49. Toffolo, M.B.; Boaretto, E. Nucleation of aragonite upon carbonation of calcium oxide and calcium hydroxide at ambient temperatures and pressures: A new indicator of fire-related human activities. J. Archeol. Sci. 2014, 49, 237-248. [CrossRef] 
50. Eliyahu-Behar, A.; Yahalom-Mack, N.; Ben-Shlomo, D. Excavation and Analysis of an Early Iron Age Lime Kiln. Isr. Explor. J. 2017, 67, 14-31.

51. Toffolo, M.B.; Regev, L.; Dubernet, S.; Lefrais, Y.; Boaretto, E. FTIR-Based Crystallinity Assessment of Aragonite-Calcite Mixtures in Archeological Lime Binders Altered by Diagenesis. Minerals 2019, 9, 121. [CrossRef]

52. Lindroos, A.; Ringbom, Å.; Heinemeier, J.; Hajdas, I.; Olsen, J. Delayed hardening and reactivation of binder calcite: Common problems in radiocarbon dating of lime mortars. Radiocarbon 2020, 62, 565-577. [CrossRef]

53. Artioli, G.; Secco, M.; Addis, A.; Bellotto, M. Role of hydrotalcite-type layered double hydroxides in delayed pozzolanic reactions and their bearing on mortar dating. In Cementitious Materials: Composition, Properties, Application; Pöllmann, H., Ed.; De Gruyter: Berlin, Germany, 2017; pp. 147-158.

54. Caroselli, M.; Hajdas, I.; Cassitti, P. Radiocarbon dating of dolomitic mortars from the convent of Saint John, Müstair (Switzerland): First results. Radiocarbon 2020, 62, 601-615. [CrossRef]

55. Regev, L.; Zukerman, A.; Hitchcock, L.; Maeir, A.M.; Weiner, S.; Boaretto, E. Iron Age hydraulic plaster from Tell es-Safi/Gath, Israel. J. Archeol. Sci. 2010, 37, 3000-3009. [CrossRef]

56. Secco, M.; Previato, C.; Addis, A.; Zago, G.; Kamsteeg, A.; Dilaria, S.; Canovaro, C.; Artioli, G.; Bonetto, J. Mineralogical clustering of the structural mortars from the Sarno Baths, Pompeii: A tool to interpret construction techniques and relative chronologies. J. Cult. Herit. 2019, 40, 265-273. [CrossRef]

57. Mills, S.J.; Christy, A.G.; Génin, J.-M.R.; Kameda, T.; Colombo, F. Nomenclature of the hydrotalcite supergroup: Natural layered double hydroxides. Mineral. Mag. 2012, 76, 1289-1336. [CrossRef]

58. Sahoo, P.; Ishihara, S.; Yamada, K.; Deguchi, K.; Ohki, S.; Tansho, M.; Shimizu, T.; Eisaku, N.; Sasai, R.; Labuta, J.; et al. Rapid Exchange between Atmospheric $\mathrm{CO}_{2}$ and Carbonate Anion Intercalated within Magnesium Rich Layered Double Hydroxide. Appl. Mater. Interfaces 2014, 6, 18352-18359. [CrossRef]

59. Ishihara, S.; Sahoo, P.; Deguchi, K.; Ohki, S.; Tansho, M.; Shimizu, T.; Labuta, J.; Hill, J.P.; Ariga, K.; Watanabe, K.; et al. Dynamic Breathing of $\mathrm{CO}_{2}$ by Hydrotalcite. J. Am. Chem. Soc. 2013, 135, 18040-18043. [CrossRef]

60. Secco, M.; Dilaria, S.; Bonetto, J.; Addis, A.; Tamburini, S.; Preto, N.; Ricci, G.; Artioli, G. Technological transfers in the Mediterranean on the verge of Romanization: Insights from the waterproofing renders of Nora (Sardinia, Italy). J. Cult. Herit. 2020, 44, 63-82. [CrossRef]

61. Frost, R.L.; Weier, M.L. Thermal treatment of whewellite-A thermal analysis and Raman spectroscopic study. Thermochim. Acta 2004, 409, 79-85. [CrossRef]

62. Frost, R.L.; Weier, M.L. Thermal treatment of weddellite-A Raman and infrared emission spectroscopic study. Thermochim. Acta 2003, 406, 221-232. [CrossRef]

63. Shahack-Gross, R.; Ayalon, A. Stable carbon and oxygen isotopic compositions of wood ash: An experimental study with archeological implications. J. Archeol. Sci. 2013, 40, 570-578. [CrossRef]

64. Asscher, Y.; Lehmann, G.; Rosen, S.A.; Weiner, S.; Boaretto, E. Absolute dating of the Late Bronze to Iron Age transition and the appearance of Philistine culture in Qubur el-Walaydah, southern Levant. Radiocarbon 2015, 57,77-97. [CrossRef]

65. Regev, L.; Cabanes, D.; Homsher, R.; Kleiman, A.; Weiner, S.; Finkelstein, I.; Shahack-Gross, R. Geoarcheological Investigation in a Domestic Iron Age Quarter, Tel Megiddo, Israel. Bull. Am. Sch. Orient. Res. 2015, 374, 135-157. [CrossRef]

66. Karkanas, P. Chemical alteration. In Encyclopedia of Geoarchaeology; Gilbert, A.S., Ed.; Springer: Dordrecht, The Netherlands, 2016; pp. 129-138.

67. Karkanas, P.; Bar-Yosef, O.; Goldberg, P.; Weiner, S. Diagenesis in Prehistoric Caves: The Use of Minerals that Form In Situ to Assess the Completeness of the Archeological Record. J. Archeol. Sci. 2000, 27, 915-929. [CrossRef]

68. Ostwald, W.Z. Studien über die Bildung und Umwandlung fester Körper. Z. Phys. Chem. 1897, 22, $289-330$. [CrossRef]

69. Koumouzelis, M.; Ginter, B.; Kozlowski, J.K.; Pawlikowski, M.; Bar-Yosef, O.; Albert, R.M.; Litynska-Zajac, M.; Stworzewicz, E.; Wojtal, P.; Lipecki, G.; et al. The early Upper Palaeolithic in Greece: The excavations in Klisoura Cave. J. Archeol. Sci. 2001, 28, 515-539. [CrossRef]

70. Borges, C.; Santos Silva, A.; Veiga, R. Durability of ancient lime mortars in humid environment. Constr. Build. Mater. 2014, 66, 606-620. [CrossRef] 
71. Hughes, J.J.; Cuthbert, S.J. The petrography and microstructure of medieval lime mortars from the west of Scotland: Implications for the formulation of repair and replacement mortars. Mater. Struct. 2000, 33, 594-600. [CrossRef]

72. Moropoulou, A.; Bakolas, A.; Bisbikou, K. Investigation of the technology of historic mortars. J. Cult. Herit. 2000, 1, 45-58. [CrossRef]

73. Pingitore, N.E. Vadose and phreatic diagenesis: Processes, products and their recognition in corals. J. Sediment. Petrol. 1976, 46, 985-1006.

74. Xu, B.; Toffolo, M.B.; Regev, L.; Boaretto, E.; Poduska, K.M. Structural differences in archeologically relevant calcite. Anal. Methods 2015, 7, 9304-9309. [CrossRef]

75. Xu, B.; Toffolo, M.B.; Boaretto, E.; Poduska, K.M. Assessing local and long-range structural disorder in aggregate-free lime binders. Ind. Eng. Chem. Res. 2016, 55, 8334-8340. [CrossRef]

76. Chu, V.; Regev, L.; Weiner, S.; Boaretto, E. Differentiating between anthropogenic calcite in plaster, ash and natural calcite using infrared spectroscopy: Implications in archaeology. J. Archeol. Sci. 2008, 35, 905-911. [CrossRef]

77. Gueta, R.; Natan, A.; Addadi, L.; Weiner, S.; Refson, K.; Kronik, L. Local Atomic Order and Infrared Spectra of Biogenic Calcite. Angew. Chem. 2006, 45, 1-5.

78. Regev, L.; Poduska, K.M.; Addadi, L.; Weiner, S.; Boaretto, E. Distinguishing between calcites formed by different mechanisms using infrared spectrometry: Archeological applications. J. Archeol. Sci. 2010, 37, 3022-3029. [CrossRef]

79. Poduska, K.M.; Regev, L.; Boaretto, E.; Addadi, L.; Weiner, S.; Kronik, L.; Curtarolo, S. Decoupling Local Disorder and Optical Effects in Infrared Spectra: Differentiating Between Calcites with Different Origins. Adv. Mater. 2011, 23, 550-554. [CrossRef]

80. Suzuki, M.; Dauphin, Y.; Addadi, L.; Weiner, S. Atomic order of aragonite crystals formed by mollusks. Cryst. Eng. Comm. 2011, 13, 6780-6786. [CrossRef]

81. Campbell, S.; Poduska, K.M. Incorporating Far-Infrared Data into Carbonate Mineral Analysis. Minerals 2020, 10, 628. [CrossRef]

82. Elsen, J. Microscopy of historic mortars-A review. Cem. Concr. Res. 2006, 36, 1416-1424. [CrossRef]

83. Karkanas, P. Identification of lime plaster in prehistory using petrographic methods: A review and reconsideration of the data on the basis of experimental and case studies. Geoarchaeology 2007, 22, 775-796. [CrossRef]

84. Thibodeau, M.L. Identifying 1 Mya Fire in Wonderwerk Cave with Micromorphology and Fourier-Transform Infrared Microspectroscopy. Master's Thesis, Simon Fraser University, Burnaby, BC, Canada, 2016.

85. Toffolo, M.B.; Ullman, M.; Caracuta, V.; Weiner, S.; Boaretto, E. A 10,400-year-old sunken lime kiln from the Early Pre-Pottery Neolithic B at the Nesher-Ramla quarry (el-Khirbe), Israel. J. Archeol. Sci. Rep. 2017, 14, 353-364. [CrossRef]

86. Toffolo, M.B.; Ricci, G.; Chapoulie, R.; Caneve, L.; Kaplan-Ashiri, I. Cathodoluminescence and laser-induced fluorescence of calcium carbonate: A review of screening methods for radiocarbon dating of ancient lime mortars. Radiocarbon 2020, 62, 545-564. [CrossRef]

87. Toffolo, M.B.; Ricci, G.; Caneve, L.; Kaplan-Ashiri, I. Luminescence reveals variations in local structural order of calcium carbonate polymorphs formed by different mechanisms. Sci. Rep. 2019, 9, 16170. [CrossRef]

88. Pachiaudi, C.; Marechal, J.; Van Strydonck, M.; Dupas, M.; Dauchot-Dehon, M. Isotopic fractionation of carbon during $\mathrm{CO}_{2}$ absorption by mortar. Radiocarbon 1986, 28, 691-697. [CrossRef]

89. Ambers, J. Stable carbon isotope ratios and their relevance to the determination of accurate radiocarbon dates for lime mortars. J. Archeol. Sci. 1987, 14, 569-576. [CrossRef]

90. van Strydonck, M.; Dupas, M.; Keppens, E. Isotopic fractionation of oxygen and carbon in lime mortar under natural environmental conditions. Radiocarbon 1989, 31, 610-618. [CrossRef]

91. van Strydonck, M.; Dupas, M.; Dauchot-Dehon, M.; Pachiaudi, C.; Marechal, J. The influence of contaminating (fossil) carbnate and the variations of $\delta^{13} \mathrm{C}$ in mortar dating. Radiocarbon 1986, 28, 702-710. [CrossRef]

92. Kosednar-Legenstein, B.; Dietzel, M.; Leis, A.; Stingl, K. Stable carbon and oxygen isotope investigation in historical lime mortar and plaster-Results from field and experimental study. Appl. Geochem. 2008, 23, 2425-2437. [CrossRef] 
93. Biasin, A.; Segre, C.U.; Strumendo, M. $\mathrm{CaCO}_{3}$ Crystallite Evolution during CaO Carbonation: Critical Crystallite Size and Rate Constant Measurement by In-Situ Synchrotron Radiation X-Ray Powder Diffraction. Cryst. Growth Des. 2015, 15, 5188-5201. [CrossRef]

94. Bowman, S. Radiocarbon Dating; British Museum Press: London, UK, 1990.

95. Wendler, J.E.; Wendler, I.; Rose, T.; Huber, B.T. Using Cathodoluminescence Spectroscopy of Cretaceous Calcareous Microfossils to Distinguish Biogenic from Early-Diagenetic Calcite. Microsc. Microanal. 2012, 18, 1313-1321. [CrossRef] [PubMed]

96. Moropoulou, A.; Bakolas, A.; Bisbikou, K. Characterization of ancient, byzantine and later historic mortars by thermal and X-ray diffraction techniques. Thermochim. Acta 1995, 269-270, 779-795. [CrossRef]

97. Yeman, C.; Christl, M.; Hattendorf, B.; Wacker, L.; Welte, C.; Brehm, N.; Synal, H.-A. Unravelling quasi-continuous ${ }^{14} \mathrm{C}$ profiles by laser ablation AMS. Radiocarbon 2020, 62, 453-465. [CrossRef]

Publisher's Note: MDPI stays neutral with regard to jurisdictional claims in published maps and institutional affiliations.

(C) 2020 by the author. Licensee MDPI, Basel, Switzerland. This article is an open access article distributed under the terms and conditions of the Creative Commons Attribution (CC BY) license (http://creativecommons.org/licenses/by/4.0/). 